\title{
Untimely Meditations on the Revolution of 1848 in France
}

\author{
EDWARD CASTLETON
}

\section{Ascribing National and International Meaning to 1848 Today}

There is something about the events of the European Revolutions of 1848 such that whenever those events are discussed, they can be endowed with a special immediacy capable of speaking to the present. ${ }^{1} 2018$ marked the $170^{\text {th }}$ anniversary of those revolutions. In France, where I live, this commemoration was largely overshadowed by the $50^{\text {th }}$ anniversary of the events of May-June 1968, deemed by the mainstream media and most major cultural institutions to be more relevant. Yet when I lectured to non-academic audiences in provincial France about 1848 for the 2018 commemoration, audiences invariably seemed to discover something in that year as equally important to understanding their own times as whatever happened in the summer of 1968. In particular, I was repeatedly confronted by spontaneous comments and questions revolving around issues of political representation. These can be summarized more or less as follows. The problems France faces today are identical to those that arose when it first experimented with universal manhood suffrage subsequent to the declaration of the Second Republic. The elected elites care little for the people who elect them, whether they be authoritarian demagogic „outsiders“, members of a semi-professional political class of ,insiders“, or „technocrats“ whose political actions focus singularly on reducing governmental balance sheets.

In an era of resurgent anti-establishment populism on a global scale, stoked by widespread dissatisfaction with the democratic political process, this sort of interpretation is perhaps natural enough. Despite the fact that the electoral franchise is fully unrestricted in most countries, unlike in the France of 1848 when only men could participate in the political process, we live in an era wherein simply being able to vote does not seem like a panacea sufficient to solve increasingly polarizing social inequalities. In France currently, there is a general opinion that the public has had the wool pulled over its eyes for too long by its politicians. This feeling has been exacerbated by the fact that citizens recently elected a consummate ,insider" and previously unelected ,technocrat" to be president in 2017 who ran for chief executive as an ,outsider“ representing change from the unpopular previous administration of which he was

This essay builds upon earlier reflections I have made on the same topic in my introduction, co-authored with Hervé Touboul. See Edward Castleton - Hervé Touboul, Retour sur 1848: peut-on en finir?, in: idem (edd.), Regards sur 1848, Besançon 2015, p. 7-31. 
a key member. As one of my colleagues at the Société Pierre-Joseph Proudhon, the French philosopher, Georges Navet, remarked in a paper on the sparring political propaganda of Adolphe Thiers and Eugène Sue during the French Second Republic at our modest société savante's annual conference held in Paris on 16 November 2018: it feels like modern history stopped at some point in late $1848 .^{2}$

Not only in France can the narrative of the events of 1848 be readily bent into a familiar arc running from hope in democracy to rampant disappointment and disdain for its supposed virtues. Here another personal anecdote seems pertinent. Having participated recently in a collective book of academic essays on 1848 and European political thought, I remember how when the first workshop for the project was organized at the University of Cambridge in 11-12 April 2012, the project was pitched both to participants and its eventual publisher, with reference to the „Arab Spring“ of 2010-2011. When the book launch party finally occurred in Cambridge on 14 March 2018, one of the editors, Gareth Stedman Jones, spoke of the book's relevance in the age of Donald J. Trump and Brexit. ${ }^{3}$ In the span of only a few years, the European Revolutions of 1848 serviceably described both how the desire to democratize political life can become contagious and how the practice of democracy can contribute to the rise of authoritarian politics and decisions at odds with enlightened opinion. It is perhaps only a question of time before the same analogy stands in, albeit in more dilated form, to describe the course of political events in Central and Eastern Europe from 1989 to the present. ${ }^{4}$

These sorts of interpretative fluctuations and spontaneous commentaries on 1848 in both France and Britain obviously have a lot to do with changes in the two countries' different national political landscapes. In this respect, historical interpretations

Georges Navet, Thiers et les pamphlets de l'Académie des Sciences morales et politiques, given at the conference, 1848. Démocratie de la Misère, Misère de la Démocratie, CEDIAS - Musée social, Paris, 16 November 2018. These conference proceedings will be published before the end of 2019.

3 Douglas Moggach - Gareth Stedman Jones (edd.), The 1848 Revolutions and European Political Thought, Cambridge 2018. In their introduction, Douglas Moggach and Gareth Stedman Jones mention both how Napoléon III would seem to anticipate Donald Trump (or at least, the latter resemble the former) and how the revolutionary contagion of 1848 would seem to find echoes in the Arab Spring and protests in Hong Kong since 2014, concluding: ,,Renewed study of the 1848 Revolutions in the current world conjuncture is therefore suggestive and fruitful for our own times. If a more optimistic tone prevailed in 2011 when this project was initiated, it would seem the course of contemporary history mirrors that of the Revolutions of 1848 themselves." Iвidem, p. 3.

4 The analogy between the events of 1848 and 1989 has already been made, with greater frequency in the decade or so following the events of 1989-90, notably around the $150^{\text {th }}$ anniversary of 1848 . See, for example, Jonathan Sperber, Preface to the English-language edition, in: Dieter Dowe et alii, Europe in 1848: Revolution and Reform, New York 2000 (German edition 1998), p. xi. I leave it to someone other than myself to prolong the analogy in a longue durée bridging three centuries and link the terminus of the revolutionary events of 1848-1849 with those of the present political conjuncture in Central and Eastern Europe. 
can seem a lot like voting itself: they tend to be judgements, however appropriate, fair, misguided, or arbitrary, on our own time as much as on the past. In light of the various constitutional confusions and uncertainties created by the results of the Brexit referendum, depending on one's level of anxieties about the future the adjective ,plebiscidal“ might rhyme in Britain much more with ,suicidal“ than elsewhere, whereas it did not when Britain voted by referendum to join the $\mathrm{EU}$ in 1975. In France, by way of contrast, given elite disregard for the 2005 national vote by referendum rejecting the European Constitution, the same adjective could be associated with the current state of political alienation and frustration to which I have already alluded; contrast this frustration with a much earlier moment, when the French citizenry came out en masse to vote in Louis-Napoléon Bonaparte's 1851 and 1852 referendums validating the coup d'État, the end of the Republic, and the latter's transformation into a Second Bonapartist Empire. ${ }^{5}$

Such interpretive fluctuations aside, there appears to be something both pertinent and paradigmatic about the events of 1848 to which historians seem almost invariably tempted to allude, much the same way there once was for many years, from the Cold War until recently a temptation to describe how modern revolutions since 1789 seem ineluctably to bequeath internal cannibalistic purges and civilian violence with the French Revolution anticipating in figurist narratives the Russian Revolution and the late eighteenth-century Terror, the early twentieth-century NKVD, Moscow show trials, and gulags. Indeed, when the authors of the Cambridge volume chose to focus on the varieties of political thought voiced during the European Revolutions of 1848, they were onto something, for not only do those revolutionary events seem striking as major moments in modern European history, they also appear to capture the beginnings of most of the ways we still frame discussions about politics and society today.

To the extent to which the way we think about things affects the way we act upon them, the overarching approach behind the Cambridge project struck me as worthwhile. In discussions concerning representative government, ethnic representation, popular sovereignty, or the proper purview of the state in intervening in economic matters, the revolutionary

Notwithstanding subsequent republican revisionism, it is worth bearing in mind that French male electors freely and overwhelmingly voted to endorse President Louis-Napoléon Bonaparte's imperial ambitions, giving him whopping majorities of $92.03 \%$ and $96.86 \%$ in the successive plebiscites of 20-21 December 1851 and 21-22 November 1852 (with both votes comprising roughly 75\% of all registered voters each time). Interestingly, dissatisfaction with the current political system in France today often translates into the demand for more referenda, despite the inconsequential aftermath of the 2005 vote (or the more consequential earlier ones of 1851 or 1852). Christopher Guyver uses the expression ,plebicidal tendencies“ to describe the repressive ideas of Thomas MARSHAL- Robert Bugeaud in his study, The Second French Republic, 1848-1852. A Political Reinterpretation, London 2016, p. 186. I owe my inspired use of the adjective ,plebiscidal“ with regards to the contemporary zeitgeist in Britain to my discovery of Guyver's own use of this apparent neologism, minus an ,s“. 
debates of mid-nineteenth century Europe undeniably brought to the fore of national debates a plethora of competing beliefs and arguments, which all continue to feel rather familiar and modern, whether they be described in ideological terms (as liberalism, republicanism, nationalism, socialism, anarchism, or conservatism, for example), or not. The editors of the Cambridge volume chose to describe the assorted struggles to shape public opinion in the battle of ideas of 1848 in avowedly Hegelian terms: ,like the mole in Hegel's analogy, they gnaw their way back to the surface after being temporarily submerged“". ${ }^{6}$ According to them, such struggles forced forever into the forefront the ,fundamental question of 1848 “, ,the nature, forms, and limits of the democratic state, the emergence of democratic modernity“, and thereby ,staked out a range of notable positions in political thought, and initiated debates which continue to resonate in our contemporary world“. ${ }^{7}$ Obviously, as with any examination of events in the past, one's appreciation of this assertion depends on who is doing the interpreting and for what purpose and to what ends, to say nothing about how one feels about ,democratic modernity“ and the Hegelian idea of ,determinate negations“. Regardless of how one answers those questions, in attempting to re-examine the events of 1848 as a ,turning point" in European political thought, the volume's editors were understandably trying to fill a void in the intellectual history and the history of political thought more generally.

What is one to make of the evolution of ideas about politics and society from the nineteenth century onwards? In recent years, a phenomenally interesting literature on eighteenth-century intellectual history has emerged, calling into question many commonplace assumptions about the course of Western European thought, but this academic cottage industry invariably stops its reassessments of the conventional wisdom with the Napoleonic era and its immediate aftermath, more or less at that exact chronological moment when political, social, and economic ideas seem to have a more obviously familiar and immediate feel to them. ${ }^{8}$ Yet it is the story of that which seems more immediately

6 D. Moggach - G. Stedman Jones, Introduction, p. 13.

Ibidem, p. 2 and 13.

For some recent examples, largely coming out of or in association with the University of Cambridge alone, see Richard Bourke, Empire and Revolution: The Political Life of Edmund Burke, Princeton, NJ 2017; Istvan HonT, Jealousy of Trade: International Competition and the Nation-State in Historical Perspective Cambridge, Mass. 2005; IDEM, Politics in Commercial Society, Cambridge, Mass 2015; Béla Kapossy et alii (edd.), Commerce and Peace in the Eighteenth Century, Cambridge 2017; IDEm et alii (edd.), Markets, Morals, Politics: Jealousy of Trade and the History of Political Thought, Cambridge, Mass 2018; Iain McDaniel, Adam Ferguson in the Scottish Enlightenment: The Roman Past and Europes Future, Harvard, Mass. 2013; Isaac Naкнімоvsкy, The Closed Commercial State: Perpetual Peace and Commercial Society from Rousseau to Fichte, Princeton, NJ 2011; Michael Sonenscher, Before the Deluge: Public Debt, Inequality, and the Intellectual Origins of the French Revolution, Princeton, NJ 2007; Michael Sonenscher, Sans-Culottes: An Eighteenth-Century Emblem in the French Revolution, 
familiar which perhaps most needs examining, particularly given that what is actual is not always so rational and vice versa. Given the present ,,actuality“ of 1848 to which I have already alluded, it surely seems that, contrary to the claims of some, the era of revolutions begun in 1789 did not end in 1989. ${ }^{9}$

Not all contemporary historians are as interested in the contents of the competing ideas in circulation in 1848 as in the circulation itself, however. There is, currently, a modish tendency amongst academics to inscribe the events of 1848 within a ,global history“ of "transnational“ contagion, which has its own respectable pedigree within academic circles. One might argue that the aforementioned events of the „Arab Spring“ had a role in this and as well as the heightened desire in the twenty-first century to dress up seemingly distant events in European history in a less parochial language capable of reaching a larger readership. So, too, has the general trend of academic writing since the 1990s to write ,transnational“, ,global“ histories. This was fully and consciously in evidence at a recent academic conference organized by the longstanding Société d'histoire de la Révolution de 1848 et des Revolutions du XIXe siècle in Paris on 12-14 December 2018 to commemorate the $170^{\text {th }}$ anniversary. A swathe of papers was given on the subjects of the impact the European
Revolutions of 1848 had on colonialism, slavery, and the extra-European world, notably in Latin America, the Caribbean, and Africa. Such topics surely have merit insofar as they have never been properly studied, but an uninformed non-specialist glancing over the conference's program might easily get the impression that the most important French actor in 1848 was Victor Schoelcher and the most important event, the definitive abolition of slavery in French territories on 27 April 1848. As for the enthusiasm that greeted the events in Paris in distant eastern places on the continent, like Prague, Budapest or Krakow, Central European urban metropolises whose educated populations felt very much like unhappy members of peripheral colonies, such excitement was not really highlighted except insofar as it affected Southern Slavic populations under Ottoman domination, perhaps because such enthusiasts did not fit some implicit phenotypic criteria of the colonized nor could be easily inscribed within narratives of the ironies of ,white/non-white“ relations. Indeed, for understandable reasons going beyond the usual Franco-centric naval-gazing and having everything to do with the history of de-colonialism and post-colonial immigration to France in the second half of the twentieth century, such a change of focus has currently come, for better or worse, to dominate the study

Princeton, NJ 2008; Richard Whatmore, Republicanism and the French Revolution: An Intellectual History of Jean-Baptiste Say's Political Economy, Oxford 2000; and Richard Whatmore, Against War and Empire: Geneva, Britain and France in the Eighteenth Century, New Haven 2012.

9 For a recent example of this claim, see Bernard Abrams's interview with John DunN, Modern Revolutions and Beyond, Contention 5, Winter 2017, Nr. 2, p. 114-131. 
of nineteenth-century French history on both sides of the Atlantic. ${ }^{10}$ With this shift in focus outwards, beyond the European Continent, it could be argued that Schoelcher's actions had greater consequences, affecting more peoples than, for instance, those ambiguities contained within Alphonse de Lamartine's famous 4 March 1848 declaration on French foreign policy, which more Eurocentric historians have traditionally found to be so critical to setting the pace for what followed. ${ }^{11}$ But where does this leave our understanding of what happened in Europe in 1848 and after more generally, and in France, specifically?

The current extra-European approach is certainly not the way in which the revolutions of 1848 have traditionally been discussed as a transnational phenomenon. Studies of the explosive spread of violence and political instability reverberating across Europe from Paris have their own successive historiographical pedigrees. ${ }^{12}$ Just as with current historiographical fashions, interpreting the revolutionary contagion of 1848 has been subject to changes in focus wrought by political events more immediately shaping historians' vision. For example, the now decidedly unfashionable British conservative historian, Lewis Bernstein Namier, himself a Polish Jew born in Russian-controlled Congress Poland and educated at the University of L'viv in Austrian Galicia, wrote of 1848 as the ,,seed-plot of European history“ and as a "revolution of intellectuals" which set Europe on the road to World War II and the Dantesque apocalypse wrought to Central and Eastern Europe during that ultraviolent ,global“ and ,transnational“ conflict long before the geopolitical chaos and bloodshed which followed in the immediate wake of the Russian Revolution and the defeat of the Central Powers in World War I. ${ }^{13}$ When developing these

10 „Les mondes de 1848“, 12-14 December 2018, Université Paris-Est Créteil. This was not the only large-scale academic conference on the 1848 Revolutions held in France for the $170^{\text {th }}$ anniversary. An international conference, „Les acteurs européens du 'printemps des peoples' 1848“, was held on more traditional topics revolving around political institutions at the Sorbonne University, 31 May 2 June 2018. For an interesting recent examination of the effects of the Revolution of 1848 on colonial life, see Silyane LARcher, L'Autre Citoyen: L'idéal républicain et les Antilles après l'esclavage, Paris 2014; and for a recent, controversial attempt to rewrite the entirety of French history in terms of its global embeddedness, see Patrick Boucheron et alii (edd.), Histoire mondiale de la France, Paris 2017.

11 On the foreign policy of the Provisional Government and the continuities of Lamartine's declaration with earlier foreign policy aims going all the way back to Richelieu, specifically with regards to the Germanophone states and Central and Eastern Europe (as opposed to the more frequently discussed Italian Question), see the still suggestive study by James G. Chastain, The Liberation of Sovereign Peoples: The French Foreign Policy of 1848, Athens, OH 1988.

12 For a recent accessible survey of the spread of revolution across Europe, see Mike Rapport, 1848: Year of Revolution, New York 2008.

13 Namier's writings on these subjects are to be found in his collection of essays. Lewis Bernstein Namier, Vanished Supremacies: Essays on European History, 1812-1918, London 1958, especially 
arguments about continental European history in 1848-1849 after 1945, Namier was motivated by a profound Germanophobia, one which he ironically enough shared with that quixotic charismatic actor of 1848 whose lifelong revolutionary activism Namier certainly could not approve of, Mikhail Bakunin. ${ }^{14}$ Namier was also sensitive to the dangers of the political use of the principle of nationalities, specifically as an attempt to undo the 1814-1815 Vienna Settlement and the Concert of Europe system, a point of view also, ironically enough, articulated much earlier than Namier's own writings and to quite different ends by another important revolutionary actor of 1848, anarchist, Pierre-Joseph Proudhon. ${ }^{15}$ Since his death, Namier has often been portrayed as a stodgy conservative Anglophile transplant hostile to social levelling, democracy and nationalism, a scholar, influenced by Vilfredo Pareto's theory of oligarchic elites, who thought all political thought was ,flapdoodle“ and who, in the words of Stedman Jones (but many, many years ago), combined ,a novel empirical method" narrowly focused on ruling class political machinations and ,,an anti-intellectualist approach to politics“" akin to ,a Nietzschean revelation of the vulgar motive behind elevated sentiment", ,a Deus ex machina that could be imposed upon any period that took the historian's fancy". ${ }^{16}$

The result is a radical devaluation of the role played by ideas in generating

p. 21-64, and his famous essay, IDEM, 1848: The Revolution of the Intellectuals, (reedition Oxford 1992 [1946]). On Namier's personal interest in the 1848 Revolutions, see James Joll's introduction to the reedition of this last work in Namier, p. v-xiii.

14 On Bakunin's Germanophobia and how it grew out of his experience of revolution in 1848-1849, see the chapter by Jean-Christophe Angaut, Revolution and the Slav Question: 1848 and Mikhail Bakunin, in: D. Moggach - G. Stedman Jones (edd.), The 1848 Revolutions and European Political Thought, p. 405-428. See also on this topic René Marie Berthier, Bakounine politique: Révolution et contre-révolution en Europe centrale, Paris 1991 (= Le Monde libertaire), and volume 2 of his series, L'autre Bakounine, Allemagne et question slave, (n.p.: Éditions du Cercle d'études libertaires Gaston-Leval, 2010), as well as, for Polish readers, the monumental two-volume study of Bakunin's evolution until 1864 done by Antoni A. Kaminski, Michait Bakunin, Życie i my, Życie i myśl: vol. I, Od religii mitości do flozofii czynu (1814-1848), Warsaw 2012; vol. II, Podpalacz Europy (1848-1864), Warsaw 2013.

15 On this subject, the topic of my habilitation work, see my preliminary studies, Edward CAstleton, Pierre-Joseph Proudhon's War and Peace: The Right of Force Revisited, in: B. Kapossy et alii (edd.), Commerce and Peace in the Eighteenth Century, p. 272-299; IDEM, Une anthropologie téléologique: fins et origins des peuples et des hommes selon Pierre-Joseph Proudhon, in: Vincent Bourdeau - Arnaud Macé (edd.), La nature du socialisme: Pensée sociale et conceptions de la nature au XIXe siècle, Besançon 2017, p. 197-242.

16 Gareth Stedman Jones, History: The Poverty of Empiricism, in: Robin Blackburn (ed.), Ideology in Social Science, Glasgow 1972, p. 96-115, especially p. 106. For a critique of Namier's influential interpretation of eighteenth-century British politics, see Quentin SkInNER, Augustan party politics and Renaissance constitutional thought, in: idem (ed.), Visions of Politics II. Renaissance Virtues, Cambridge 2002, p. 344-367, especially p. 349 ff. 
historical change, in the words of the British Marxist, Perry Anderson, a ,,mindless history" without any motor driving its course in which only a ,vulgar psychologism" flimsily buttressed Namier's penchant for „,history voided of ideas“. ${ }^{17}$ However, regardless of the deficiencies wrought by his own Anglophilic conservative political biases, Namier did admirably highlight the disparity in 1848 between the worldview of the urban educated professional classes longing for greater democracy and constitutional independence from traditional conservative social elites across the Continent and the vast uneducated peasantry, relatively indifferent to greater levels of democracy and constitutional government, but especially sensitive in Central Europe to the material abuses of serfdom and its vestiges such as the hated practice of the robot. Surely this aspect of the 1848-1849 Revolutions is relevant today, anticipating the dangers for contemporary democracies of widespread educational inequalities in an era of unrestricted freedom of the press, since powerful economic groups have proven themselves readily able to use lower-class resentment against urban professionals to their political advantage just as they did 170 years ago. The Germanophobe Namier was chiefly preoccupied with the rise of Hitler and how the consecration in 1938 of the Anschluss grew less than one hundred years earlier out of the grandiose aspirations and ineffectual machinations of Rhineland republicans and democrats at the Frankfurt Parliament in 1848-1849.
Nonetheless, his critique of the ,revolution of the intellectuals" could surely be recast in the present era of such diverse phenomena as the electoral successes of Viktor Orbán and the inchoate demands of the gilets jaunes movement in France, in which popular anger and resentment with aloof political elites divorced from the concrete material anxieties of the majority of individuals over whom they rule overlaps with geography, education, and income.

\section{Getting Past Marxist Legacies}

In casually alluding to such very different contemporary interpretative possibilities and current historiographical trends in our own era, I want now to stress just how much the preoccupations of academic historians have changed since when I was an undergraduate at the University of Chicago in the early 1990s. If history is written by the winners, the overwhelming cultural winners in academic life in elite Western universities since the second half of the $20^{\text {th }}$ century (particularly in the United States) have been left-leaning university professors generally interested in those assumed to be the history's social losers, whether of 1848 or of world history at large. In such recondite places during my undergrad years, the influence of Marxism was unquestionably greater than Namierism in setting research agendas exploring nineteenth-century European history. Over the course of the 1970s and early 1980s, there emerged a general consensus joining the research efforts of historians, sociologists, and political

17 Perry Anderson, English Questions, London 1992, p. 73, 75-76. 
scientists that when it came to studying modern revolutions from the French Revolution onwards, in an era when ,,capitalism" was the dominant economic form, their political origins should be downplayed in favor of the study of those social typologies most apt to engage in protest and confrontation with established socioeconomic orders and the governments providing their protection. One of the discoveries emerging from this research trend (and one whose conclusions were invariably inscribed, like Marxism itself, within underlying narratives of economic modernization and development), was that contrary to the Marxist hypothesis, often preindustrial artisanal or agrarian elements were more likely to engage in violent class conflict than the unskilled urban proletariat. ${ }^{18}$ Inspired by the social and political turmoil of the 1960s and 1970s, such academic work had an effect on the way the mid-nineteenth-century revolutions were discussed by the time I was taking classes about French history. By the 1990's, the usual discussion of 1848 revolved around a reading of Marx's 1850 Class Struggles in France articles and his 1852 broadside, The Eighteenth Brumaire of Louis Napoleon, followed by an examination of the historical accuracy of Marx's account as could be gleaned in the works of the historians Roger Price and Mark Traugott. ${ }^{19}$ Traugott's careful study of the social composition of both sides of the barricades during the June Days in Paris considerably problematized Marx's rendition of the June Days as ,the first great battle $[\ldots]$ fought between the two classes that split modern society" since there was

18 For two very different criticisms of this literature, see Gareth Stedman Jones, The Mid-Century Crisis and the 1848 Revolutions: A Critical Comment, Theory and Society 12, July 1983, Nr. 4, p. 505-519; and, insofar as this literature applied to French social history, Jacques Rancière, The Myth of the Artisan, International Labor and Working-Class History 24, 1983, p. 1-16. The other essays on the mid-nineteenth century socioeconomic crisis in England, France, and Germany, published in the same issue of Theory and Society as Stedman Jones's, are fairly representative of critical academic approaches to 1848 made in the early 1980s in light of this larger literature. For criticism of the underlying narrative presuppositions contained within this academic literature about economic development in the transition from „pre-capitalist“ societies to „,capitalist“ ones, see the highly succinct remarks about the ,,proto-industrialization“ hypothesis made by Charles F. SABEL, Protoindustry and the Problem of Capitalism as a Concept: Response to Jean H. Quataert, International Labor and Working-Class History 33, Spring 1988, p. 30-37, as well as his classic essay revising commonplace assumptions about industrial history, co-authored with Jonathan ZeITLEN, Historical Alternatives to Mass Production: Politics, Markets and Technology in Nineteenth-Century Industrialization, Past and Present 108, August 1985, Nr. 1, p. 133-176, and the collection of historical essays they both edited, IDEM (edd.), World of Possibilities: Flexibility and Mass Production in Western Industrialization, Cambridge 1997.

19 Roger Price, The French Second Republic: A Social History, London 1972; Mark Traugott, Armies of the Poor: Determinants of Working-Class Participation in the Parisian Insurrection of June 1848, New Brunswick $2002^{2}$ [1985]. See also the work of one of my teachers at Chicago, Roger Gould, who arrived at similar conclusions as Traugott's in his study of the sociological composition of active participation in the Paris Commune, Roger Gould Insurgent Identities: Class, Community, and Protest in Paris from 1848 to the Commune, Chicago 1995. 
much sociological overlap between the insurgents and the gardes mobiles. ${ }^{20}$ The point has been made that Marx's frequent narrative use of vitiating parasitic subclasses (like the petite-bourgeoisie or the lumpenproletariat), internal ruling class fractures (like those pitting landed against moveable property, or industrial against financial capital), or retrograde lower classes (like the peasantry) to explain the inability of the proletariat ultimately to triumph over the bourgeoisie was highly questionable, to say the least, and similar in kind to his preoccupation from 1848 until his death with explaining why ,capitalism“ had not yet collapsed (even though it should and was always just on the verge of doing so). ${ }^{21}$ One can find the same sort of invidious privileging of certain collective categories over others in Engels's writings from 1849 about the Slav question and such ,non-historic peoples“ as the Czechs or the Slovenians, whose nationalist aspirations did not deserve the same serious geopolitical consideration as those of the Poles or the Magyar Hungarians, for instance. ${ }^{22}$

The early 1990s were an era when Marxism, although waging a rearguard action, still had some intellectual currency among academics seemingly of subversive political import in the US and Western Europe, and older research agendas about „working-class formation“ continued to be discussed in elite universities by social historians, historical sociologists, and political scientists while trade unions themselves were waging their own rearguard struggle to survive in the decade of commercial and industrial globalization that followed the end of the Cold War. However, as the collapse of the Soviet Union and ,really

20 For a recent survey of who manned the barricades during the Second Republic, see Louis Hincker, Citoyens-combattants à Paris, 1848-1851, Villeneuve d'Ascq 2008.

21 For two different accounts of Marx's application of class analysis to the 1848-1851 period in France for his larger narrative purposes, both working in the critical wake of Louis Althusser, see Jacques Rancière, Le Philosophe et ses pauvres, Paris 1983, p. 87-184, especially p. 135-155; Dominick LACAPra, Rethinking Intellectual History: Texts, Contexts, Language, Ithaca, NY 1983, p. 268-290. Since then, there have countless more. For some recent examples, see Raphael Hörmann, Social Tragedy and Political Farce: Marx's Poetics of History and Revolution, in: Christopher Hamilton et alii (edd.), Facing Tragedies, Münster 2009, p. 203-214; IDEM, Writing the Revolution: German and English Radical Literature, 1819-1848/49, Münster 2011, and the successive examinations of Marx's pre-Class Struggles articles on France for the Neue Rheinische Zeitung, his Class Struggles, and his Eighteenth Brumaire in intellectual biography Gareth Stedman Jones, Karl Marx: Greatness and Illusion, London 2016, p. 268-272, 305-313, 334-342. On the topic of Marx's difficulties in describing how ,capitalism“ would end as well as his mature difficulties in theorizing what societies would look like after its downfall, see G. Stedman Jones, Karl Marx, p. 375-431, 568-586; and on the idea that these conceptual difficulties might have even preceded the drafting of the Manifesto and the 1848 Revolutions, see Keith Tribe, Karl Marx's Critique of Political Economy: A Critique, in: his stimulating collection of essays, The Economy of the Word: Language, History, and Economics, Oxford 2014, p. 172-254.

22 See Roman Rosdolsky's polemical study on this topic, Roman RosDolsky Engels and the 'Nonbistoric' Peoples: The National Question in the Revolutions of 1848, Glasgow $1987^{2}$ [1979]. 
existing socialism " faded into distant memories (admittedly more easily for Western Europeans and Americans than for Eastern Europeans and Russians), the importance of confirming or discrediting Marx's account with regards to concrete expressions of social protest, dissatisfaction, and revolution became less important for historians.

Yet Marx certainly did succeed in his afterlife to the extent that his two most important texts on the French Second Republic, minor in his lifetime, have become canonical in Western universities, frequently still taught along with Tocqueville's posthumous Souvenirs as primary sources in university courses on the historical period. This is quite an achievement given that these writings' almost complete obscurity at the time of their publication contrasted with the interest in works by contemporaries treating the same topics such as Daniel Stern, Proudhon, or even rival Hegelian Lorenz von Stein. It is also quite an accomplishment given the questionable historical reliability of Marx's successive accounts of the tumultuous life of the Second Republic. Hard pressed as scholars such as Price and Traugott once were back in the 1980s to prove or disprove Marx's assumptions about class composition, it is difficult today to argue that the June Days, for example, were provoked by a capitalist employer class unless the Provisional Government itself were to be thought of as the ultimate capitalist. As contemporaries like Stein recognized, by guaranteeing the right to work on 25 February 1848, the Provisional Government set up a novel legitimacy crisis in which the government appeared to be the guarantor of last resort for employment as unemployed workers flooded Paris. ${ }^{23}$ In the June Days, social unrest revolved around state behavior (the closing of the National Workshops), and not the

23 On Stein's interpretation of the events of 1848, see Diana Siclovan, Le ,movement social“ et la naissance de la ,démocratie sociale“: 1848 selon l'interprétation de Lorenz Stein, in: E. Castleton H. Touboul (edd.), Regards sur 1848, p. 361-387. Interestingly, when I first learned of Stein's 1850 Geschichte der Sozialen Bewegung in Frankreich von 1789 bis auf unsere Tage, it was not in the same nineteenth-century French history class at the University of Chicago in which I read Marx, Tocqueville, Traugott, Price, etc., but in a class on the origins of the European welfare state, largely driven by late twentieth-century left-wing discussions about the „fiscal crisis of the state“, the „,contradictions of the welfare state“, the vicissitudes of „risk society“, and Michel Foucault's theory of ,governmentality“ as presented in a book of essays written by admirers entitled The Foucault Effect. In this class, Stein was presented as someone who had anticipated many of the problems addressed much, much later in the 1970s and 1980s by James O'Connor, Claus Offe, Ulrich Beck, and François Ewald, all of whom were working within the conceptual framework of revisionist Marxist and post-Marxist critiques of the welfare state. This sort of singular focus was perhaps understandable enough, given that memories of Reagan and Thatcher were fresh enough in everyone's minds, and that in the United States, serious welfare reform was being enacted by a President who prided himself on being a „New Democrat“. Nevertheless, the possible interest of reexamining Stein's ideas for the purposes of revising earlier research agendas regarding the various crises of mid-nineteenth-century European history was revealingly not that apparent in the early 1990s to social historians of France largely oblivious to any German reception of the events of 1848 in France beyond the collected works of Marx and Engels. 
injustices committed by any capitalist class. The violent repression that followed disproved commonplace radical republican assumptions during the July Monarchy that social democracy and political liberalism were compatible with one another. The related assumption that universal manhood suffrage would not produce conservative governments was likewise disproven by the legislative elections which preceded the June Days and the December presidential election which followed them. These were political lessons, ones acquired with a great deal of bitterness by many left-wing republicans and socialists. If there was a class struggle in 1848 whose history scholars should recount, it would seem to have been more political than economic in nature. ${ }^{24}$

It is perhaps on the basis of this insight that ,anarchism“, to the extent that this intransigent form of radical anti-statism has any ideological coherence, was born in France, and it is no coincidence that this particular discursive form of radicalism not only rejected the panacea of elections in the name of a different conception of emancipation, but also was distinctly anti-bourgeois in tone. Although the founder of a rival ideological tradition, much less hostile in principle to party politics, Marx seems to have presciently anticipated this when he asserted with Engels in their 1848 Communist Manifesto: ,The executive of the modern state is nothing but a committee for managing the common affairs of the whole bourgeoisie“. Indeed, after the disappointments of 1848 , this would become a common trope in the critique of parliamentary democracy well into the 1930s. This reflects a change from the first half of the nineteenth century when the European middle classes were often perceived politically by contemporaries in terms of their struggle against those vestiges of the Old Regime, like the aristocracy, and in favor of of a moderate liberal constitutionalism. ${ }^{25}$ If the middle classes were once widely assumed to be the social embodiment of progress and modernity, in France after 1830, and then 1848 , it became apparent to many that outward professions of political liberalism frequently overlapped with the inward aspirations for power of those who felt wealthy and entitled enough to campaign for office but who were hostile to seeing the unpredictable working classes fully integrated into political life.

24 This obviously was even more the case before 1848, under the restricted suff rage of the July Monarchy in which participation in political life was dependent on property assessments over a certain value. Things have changed considerably in the 170 years since then. Generally speaking, today in Western Europe and North America, the more capital one has, the more one tries not to pay taxes rather than the opposite. On the other hand, levels of inequality in wealth are shockingly comparable with the nineteenth century, particularly when one juxtaposes wealth disparities in July Monarchy France with those in the United States today.

25 On this topic of the middle classes and the effects of 1848 on their conceptualization in both Britain and France, see Gareth Stedman Jones, Elusive Signifiers: 1848 and the Language of 'Class Struggle', in: D. Moggach - G. Stedman Jones (edd.), The 1848 Revolutions, p. 429-451. See also Sarah Maza, The Myth of the French Bourgeoisie: An Essay on the Social Imaginary, 1750-1850, Cambridge, Mass. 2003. 
Indisputably, the idea prior to 1848 that one could resolve the „social question“ resulting from the tension between legal equality and material inequality through greater access to voting proved itself to be a chimera during the short life of the French Second Republic. Once all French males could vote, elections just brought back the old elites, the vast majority of whom never wanted a republic or the February Revolution in the first place. Political notables from the July Monarchy like Odilon Barrot, Gustave Beaumont, Jules Dufaure, Alfred de Falloux, Léon Faucher, Louis-Mathieu Molé, CharlesRené-Forbes Montalembert, Charles de Rémusat, Thiers, and Tocqueville and top military brass like Marshal Thomas-Robert Bugeaud or Generals Achille Baraguey d'Hilliers, Louis-Eugène Cavaignac, Nicolas-Anne-Théodule Changarnier, and Léon-Louis-Christophe Juchault de La Moricière all played prominent political roles in the Second Republic, much like they had under Louis-Philippe. Indeed, if Louis-Napoléon Bonaparte was able to be elected President in December 1848, it was initially through the efforts of Molé and Thiers, who naïvely both believed they could use him as a tool. The ultimate triumph of the Prince-Président, however, showed that even the July Monarchy's aristocratic and bourgeois political class could not hold power indefinitely under conditions of universal manhood suffrage. Its members could never fully instrumentalize political life to anti-democratic ends, as the public relations disaster which was the successful legislative passage of the 31 May 1850 measure limiting suffrage would prove to their detriment. Ironically, the story of their failure, one which would seem to call into question the confident elitism of a Naimierite approach, would also be that of the rise of a new kind of politics, one in which a fusion of nationalism, democracy, and authoritarianism could unpredictably be harnessed to electoral and plebiscitary victories via the vehicle of something once called „Caesarism“ and now given a fashionable neologism borrowed from political science, ,„démocrature“, by Francophone journalists and political commentators keen to describe current manifestations of this same phenomenon in our own era. ${ }^{26}$ But as a salutary recent English-language history of the Second Republic makes clear, the history of what happened in high politics in France between 1848 and 1852 had little to do with whether or not the lumpenproletariat composed the garde mobile that shot at insurgents in June 1848 or attended rallies for Louis-Napoléon Bonaparte before he became Napoléon III. On the contrary, it had everything to do with the initial successes and ultimate failure of a political elite inherited from the July Monarchy, which sought to control universal manhood suffrage to its advantage but was too divided to act decisively enough ever to reconsolidate its power. ${ }^{27}$

\footnotetext{
26 In current Anglophone poli-sci jargon, the term used is „democratorship“.

27 See Ch. Guyver, The Second French Republic, 1848-1852. A Political Reinterpretation. The title of Guyver's book is a bit of a misnomer since, less than a general historical overview of politics from
} 
Facilitating the displacement of earlier research fixations on the possible correlations between social protest and modernization, one of the key insights growing out of the ,linguistic turn" in the 1980s and early 1990s that de-Marxified Anglo-American academic approaches to the study of social history was that the very language of class was often shaped by efforts to change the political system (and not by its exclusive conformity to economic necessities). ${ }^{28}$ Class consciousness could be said to be dependent on fluid feelings of exclusion and inclusion such that the fluctuations of political life might arguably create plural forms of class consciousness and social identities just as much as the opposite might equally be true. Although this insight seems best applied to social and political history prior to the generalization of universal suffrage in Western societies between 1850 and 1950, it is pertinent in the context of this essay. Once universal manhood suffrage was granted in France by the Provisional Government in 1848 , it was no wonder that the mass of political neophytes that comprised the majority of the French nation might not fit into neat social categorization the same way the much more sociologically circumscribed older political establishment of electors and elected did. The confusion wrought by universal manhood suffrage makes it hard to argue that the Second Republic fell entirely victim to the oppressive domination of a perfidious ruling class since the révolution escamotée of 1830 decried by progressive liberals, republicans, and socialists alike during the July Monarchy was subsequently a work of democratic self-sabotage in 1848. Historians today should have better things to do than to look for pure, unvitiated sociological expressions of class struggle directly related to the unfolding of competing modes of production.

\section{French Attempts to Control an}

\section{Accidental Revolution, Past and Present}

Once one becomes attentive to the malleable interrelation between class identity and political life, one can perhaps better appreciate just how accidental the February Revolution of 1848 actually was, since it certainly was not wanted by those

the fall of Louis-Philippe until the November 1852 plebiscite calling for the recreation of a Bonapartist empire, it is almost entirely focused on the effects the vicissitudes of political life had on elite opinion in the short lifespan of the ephemeral republic. However, the author has assured me in private correspondence that the title he originally wanted to give to his study, regrettably nixed by his publisher, was The Impossible Republic.

28 On this subject, see Gareth STEDMAN JonEs's groundbreaking collection of essays, Languages of Class: Studies in English working class history, 1832-1982, Cambridge 1983, as well as his more recent reflections on the conceptual significance of this earlier work, IDEM, The determinist fix: some obstacles to the further development of the linguistic approach to history in the 1990s, History Workshop Journal 42, 1996, p. 19-35; IDEm, Anglo-Marxism, Neo-Marxism and the Discursive Approach to History, in: Alf Lüdke (ed.), Was bleibt von marxistischen Perspektiven in der Geschichtsforschung, Göttingen 1997, p. 149-209; and IDEM, The Return of Language: Radicalism and the British Historians, 1960-1990, in: Willibald Steinmetz (ed.), Political Languages in the Age of Extremes, Oxford 2011, p. 331-349. 
reformers who unwittingly initiated it in the debates about electoral reform in 1847. ${ }^{29}$ Generally, revolutions do not unfold as they were imagined or anticipated before their occurrence, and the collapse of monarchy in France was no exception to this rule. When Prosper Duvergier de Hauranne, a leading member of the dynastic opposition under the July Monarchy, initiated a campaign for electoral reform in early 1847 , he only sought to halve electoral qualifications from 200 to 100 francs and make the criteria for political ,capacity" be based not just on fiscal qualifications (i.e. the ownership of property) but also on diplomas and other educational certificates attesting to the superior degree of intelligence assumed necessary for voting, adding some seats to the Chamber of Deputies and increasing the number of members of the electoral colleges in the process. Duvergier's measure was supplemented by the opposition's desire, led by Rémusat, to stop functionaries from being able to be simultaneously deputies, a source of political corruption claimed to be worse for France than social inequalities. ${ }^{30}$ Neither Duvergier nor Rémusat anticipated the banquet campaign which followed and whose hijacking by radical republicans, when coupled with Prime Minister François Guizot's intransigence and Louis-Philippe's hesitations, led to the February Revolution, the abdication of the monarch, the declaration of a republic based on universal male suffrage, and, in keeping with the spirit of Rémusat's earlier proposal, the stipulation that political representatives of the new assembly should be salaried at 25 francs a day. Likewise if creating a wage-earning professional political class had long been thought of by the liberal opposition under the July Monarchy as an anti-corruption measure, the republicans who finally passed the measure could not have anticipated that, only a few years later, popular mockery of deputies' daily 25 francs would enthusiastically welcome Louis-Napoléon Bonaparte's 1851 coup d'état.

Liberal reformers of the July Monarchy were not alone in not foreseeing France's immediate political future. Some of their most radical critics could not see what was coming either. Observing Guizot's attempt to quash Duvergier's proposal, Proudhon followed those legislative debates which would unintentionally prove to be the monarchy's undoing with intense interest. Expressing his spontaneous disdain for the much-vaunted virtues of the educated classes, he noted in his carnets: „Why did Monsieur Guizot not dare say that intellectual capacities are the most corruptible, the most corrupt, and generally the most cowardly,

29 On this subject, see concise overview William Fortescue, France and 1848: The End of Monarchy, London 2005.

30 On the theme of corruption on the eve of the February Revolution, see IDEM, Morality and Monarchy: Corruption and the fall of the regime of Louis-Philippe in 1848, French History 16, 2002, Nr. 1, p. 83-100. 
the most perfidious of all capacities... „A scholar is a shit..." ${ }^{31}$

Rejecting intra-elite attempts to redefine the official circumscription of the political power of the ruling class, Proudhon condemned those reformers he believed wished to create a new aristocracy through a less restricted definition of the electoral criteria for ,,political capacity," one privileging the meritocratic acquisition of advanced degrees and making the less rich members of the upper middle classes as equally fit to govern as their traditional social betters. But he also was reflecting, without knowing it, on the origins of what would become, via the subsequent banquet campaign the February Revolution of 1848, an event French elites did not any better anticipate in 1847 than members of the Provisional Government did the rise of Louis-Napoleon Bonaparte in the early months of 1848 . For that matter, Proudhon's derogatory observation about „scholars" presaged in ways he himself could not have anticipated the outward hostility to socialism subsequent to the February Revolution of 1848 shown by writers, philosophers and economists as diverse as Victor Cousin, Gustave Flaubert, Joseph Garnier, Xavier Marmier, Prosper Mérimée, Louis Reybaud,
Thiers, or Louis Wolowski, to say nothing of all the members of France's Academy of Moral and Political Sciences not already mentioned in this list. Just as the experience of the events of 1848 fortified anti-bourgeois sentiment already present in France since 1830, it also consolidated anti-socialist sentiment inspired by the emergence of the only real novel force in French political life during the Second Republic: „la démocratie sociale“. Thus, French liberal political economists who did not object to socializing with the likes of Proudhon or August von Cieszkowski before February 1848 found themselves hard at work after the February Revolution discrediting those dangerous ideas they considered responsible for the National Workshops, the Luxembourg Commission, or the popular right-to-employment demands of the various démocsocs. The slow conservative evolution of Michel Chevalier from Saint-Simonian to free trade advocate, in which a crucial turning point was the systematic critique of the ,droit au travail“ he developed between 1844-1848, was testimony to this, as was the publication of the monumental conceptual breviary to liberal political economy which was the 1852-1853 Dictionnaire de l'économie politique. ${ }^{32}$

31 Pierre-Joseph Proudhon, Carnets, Dijon 2005, p. 478. On the context in which this remark was made, see Edward Castleton, The Many Revolutions of Pierre-Joseph Proudhon, in: D. Moggach G. Stedman Jones (edd.), The 1848 Revolutions and European Political Thought, p. 39-69, as well as my long introduction to the first two volumes of my critical edition of unpublished manuscripts, Pierre-Joseph Proudhon, La Propriété vaincue et d'autres manuscrits inédits, 1840-1850, Besançon, forthcoming in 2019.

32 Charles Coquelin - Gilbert Guillaumin (edd.), Dictionnaire de l'économie politique I-II, Paris 1852. On the subject of the ideological awakening of anti-socialism during the Second Republic and various establishment attempts to wage a propaganda campaign against the propagation of 
Such adversaries willfully mischaracterized the ideological unity of the French socialists they opposed in 1848. Nowhere was there greater diversity of ideas and nuance in varieties of socialism than in France, certainly more so even than in the Rhineland, where the conflicts pitting Marx against Andreas Gottschalk pale in theoretical interest when compared with those, for example, pitting Proudhon against Louis Blanc or Pierre Leroux. In the first year of the French Second Republic, competing arguments abounded about the importance of the „organization of labor“", the ,organization of credit“, the "right to work" and how best to organize ,l'association“ (a word of particular illocutionary power amongst the démoc-socs). Even more loudly than under the July Monarchy, socialists quarreled as much with each other as with their non-socialist opponents. ${ }^{33}$ There was so much polemical agitation over different socialist demands to improve the distribution and circulation of wealth during the Second Republic that in the ensuing confusion even press baron Emile de Girardin was considered by many contemporary observers insensitive to the finer points of the resulting to-and-fro, including Karl Marx, to be an ,,anarchist“ associated with Proudhon, his regular sparring partner. Attentive foreign observers like Lorenz von Stein had picked up on the interest of such intellectual excitement as early as 1842. Stein believed that the significance

socialist ideas and in favor of the supposed virtues of private property, see Thomas Bouchet, Le droit au travail sous le 'masque des mots': Les économistes français au combat de 1848, French Historical Studies 29, 2006, Nr. 4, p. 595-619; Jean-Pierre Cotten, Cousin et 1848, in: E. Castleton - H. Touboul (edd.), Regards sur 1848, p. 173-202; Guillaume Cuchet - Sylain Milbach, The Great Fear of 1852, French History, 26, 2012, Nr. 3, p. 297-324; Hélène Dess rousses, Autour de 1848. Le débat entre 'socialisme' et 'libéralisme', Cahiers pour l'Analyse concrète 37-38, 1998, p. 77-94; François Fourn, 1849-1851, l'anti-communisme en France: le spectre rouge de 1852, in: Sylvie Aprile et alii (edd.), Comment meurt une République? Autour du 2 décembre, Paris 2004, p. 135-152; Sophie-Anne Leterrier, L'Institution des sciences sociales. L'Académie des Sciences morales et politiques, 1795-1850, Paris 1995, p. 311-331; and the now ancient article by Georges Navet, Le Cogito propriétaire et son histoire (M. Thiers défenseur de la philosophie), Le Doctrinal de Sapience 6, October 1979, p. 95-119. On Chevalier's longer intellectual evolution and his ambiguous relation to economic liberalism, see Michael Drolet, Industry, Class and Society: A Historiographical Reinterpretation of Michel Chevalier, English Historical Review 123 (504), 2008, p. 1229-1271. Chevalier's ambiguous relation to economic liberalism was perhaps indebted to Saint-Simon's earlier indebtedness to liberal political economy. See Gareth Stedman Jones, Saint-Simon and the liberal origins of the socialist critique of Political Economy, in: Sylvie Aprile - Fabrice Bensimon (edd.), La France et l'Angleterre au XIXe siècle. Échanges, représentations, comparaisons, Paris 2006, p. 21-47.

33 On the rhetoric of , association “ in the idiom of working-class militants from the Second Republic, see the lexicometric study by Maurice Tournier, Quand un mot en cache d'autres: le vocabulaire de l'association en 1848, in: idem (ed.), Des mots sur la grève, propos d'étymologie sociale I, Paris 1992, p. 135-153, and, in much greater detail, his doctoral dissertation, IDEM, Un vocabulaire ouvrier en 1848. Essai de lexicométrie, Paris 1976. Although Tournier's work is slightly marred both by its proleptic fixation on seeing incipient signs of the rise of trade unions in 1848 and a general lack of conceptual interest in the vast corpus of texts examined, it still has the advantage of a thorough empiricism. 
of the proliferation of socialist ideas in France prior to the February Revolution was in foreshadowing a larger Hegelian shift from the importance of politics to that of society through the interplay of contradictory post-revolutionary aspirations for greater levels of independence and dependence. Regardless of the accuracy of his teleological reflections, nowhere else than in France would socialist ideas and activists play as big and influential a role in national political life in 1848 , courtesy of relative press freedom and open elections. Yet most French socialists, although favorable to the expansion of suffrage, had not developed their ideas since 1830 with the hopes of realizing them through participation in the electoral process. Consequently, the unexpected collapse of the monarchy was bound to produce confusion for them, too.

Because socialism's political presence in 1848 represented a singular departure from the aforementioned continuities in figures and factions from the July Monarchy who carried on in the Second Republic, some recent French scholars sympathetic to their nation's radical history and to its traditional mascots such as workers and women have chosen to highlight anew the democratic awakening of different, underrepresented social groups outside the official sphere of traditional political life and which they associate with ,,modernity“. ${ }^{34}$ The resulting focus on the various social democratic enthusiasms of 1848 has its merits, although it is bound to confine itself chronologically to the year 1848 in light of the innumerable left-wing disappointments of 1849,1850 , and $1851 . .^{35}$ For one thing, it has allowed scholars to chart the emancipatory effects of competing discourses of participatory democracy, representation, and ,,association" on previously marginal groups whose actions helped forge, for example, the "labor movement" in a fashion far different from the straightforward

34 For some recent examples of this tendency, see, for the workers, Samuel Hayat, 1848: Quand la République était révolutionnaire, Paris 2014, and, (in English, Working-Class Socialism in 1848 in France, in: D. Moggach - G. Stedman Jones, The 1848 Revolutions and European Political Thought, p. 120-139; and, for the workers and women, Michèle RIOT-SARCEY, Le procès de la liberté: une histoire souterraine du XIXe siècle en France, Paris 2016.

35 This is particularly evident in attractive iconographic account produced by Maurizio GribaUd Michèle Riot-SARCEy, 1848: la revolution oubliée, Paris 2008, which gives a day-to-day discussion of the key events between the February Revolution to the June days only abruptly to transition to a short epilogue coveringh the rest of the year, entitled, ironically enough, „L'amnésie de la revolution“. The same thing is true of S. HAYAT's, 1848: Quand la République était révolutionnaire, which regrettably also ends with the June Days, whereas some discussion of the socialist and republican debates about „direct legislation“ and the need to rethink popular sovereignty in the wake of the 31 May 1850 law severely restricting voting in large urban areas would have reinforced his overarching argument about the insufficiencies of the constitutional conception of political representation under the Second Republic. See, on this latter topic, Anne-Sophie Cнамвоsт, Proudhon et l'opposition socialiste à la loi du 31 mai 1850: face à la trahison des représentants, Revue française d'histoire des idées politiques, 31/1 2010, p. 81-107, and her chapter IDEM, Socialist Visions of Direct Democracy, in: D. Moggach - G. Stedman Jones, The 1848 Revolutions and European Political Thought, p. 94-119. 
materialist class determinism of the orthodox Marxism of old. ${ }^{36}$

Nevertheless, the fact remains that such rhetorical outpouring, however much it might have attempted to change more restricted conceptions of political representation, did not change the course of French political history to its advantage between the reigns of Louis-Philippe and Napoleon III. ${ }^{37}$ By focusing exclusively on the sundry but often sincere discursive democratic enthusiasms of 1848, one is left wondering why both the Second Republic, in general, and démoc-soc ideas, in particular, failed so spectacularly. This was not a question forgotten by French republicans and socialists in the Third Republic. They realized that one of the reasons that left-radicalism was crushed so easily during the Second Republic (and so violently so violently during the 1871 Paris Commune) was due to its overwhelmingly urban and Parisian bias, and that conceptual innovativeness and countless print publications in a democratic age would not be enough. They recognized that were republicans and socialists ever to see their ideas put into practice, they would have to leave their geographic and social comfort zones and that there would need to be more Red Republicans than those to be found in December 1851 in some scattered insurrectionary places in Southern France. ${ }^{38}$ This was a point perhaps more obvious to earlier French historians like Maurice

36 This is particularly the case with Hayat's suggestive work, which revisits debates about the representation of labor in the first year of the Second Republic in an innovative fashion, despite remaining, in my opinion, too attached to the class component in the expression of socialist ideas insofar as that component relates to the larger history of the French „labor movement" described in now 40-year old historical surveys by William H. Sewell Jr. and Bernard H. Moss.

37 For this point, see S. Снамвоsт, Socialist Visions of Direct Democracy, p. 104.

38 One of the reproaches made to a book I co-edited on the French socialist press was that there was no mention of Pierre Joigneaux's rural Burgundian journal, La Feuille du village or any of the many other démoc-soc newspapers in circulation outside of Paris in the provinces during the Second Republic. Indeed, the only provincial paper discussed in the book (if one ignores the numerous Lyonnais silkworkers' papers) was George Sand's L'Éclaireur de l'Indre, which got a brief mention within an article on Sand and Pierre Leroux's La Revue Indépendante. See Thomas Bouchet et alii, Quand les Socialistes inventaient l'avenir, 1825-1860, Paris 2015, p. 244. The criticism was pertinent, and undoubtedly reflected the urban biases of the book's editors (myself included). Indeed, studies of the revolution of 1848 in the provinces have long since died in France. Apart from the numerous American studies of French provincial cities and politics in the Second Republic from the 1970s and early 1980s, (notably by Robert Aminzade, John M. Merriman, and Ted W. Margadant), and the work on nineteenth-century French rural politics by the Australian historian of France, Peter McPhee, the last serious French survey of this question I can remember was Philippe Vigier's, La Vie quotidienne en province et à Paris pendant les journées de 1848, Paris 1982. For a recent example bucking this general trend (but revealingly written by an octogenarian), see Pierre Merlin, La formation d'une opinion démocratique: Le cas du Jura, de la révolution de 1848 aux années de la „République triomphante“ (vers 1895), Besançon 2018. See also the stimulating iconographic presentation of Anne VERDURE-MARY, La Révolution de 1848 $\grave{a}$ Besançon. Entre ralliement et dissidence, in the catalogue of an exhibit held at a provincial municipal library for a recent commemoration of 1848, BibliothèQues et Archives municipales (ed.), 1848: „On sera heureux maintenant!“, Besançon 2018, p. 43-64. 
Agulhon and Philippe Vigier, who were conducting their research not long after the Vichy Regime and during the urban social protests of the 1960s and were, therefore, more obviously sensitive to the problem of how a republican form of government could emerge in a largely rural nation, and how the solution to this problem might or might not relate to the larger question of; „modernization“. 39

One sometimes regrets that in the wake of both the massive cultural centralization undergone by France since 1945 and the cacophony of venues for expressing one's opinion wrought by the Internet since the end of the twentieth century, today's largely Parisian left-leaning intellectuals, often securely protected in university sinecures, have not learned the earlier hard-won lesson that not everyone thinks like urban elites. Again, this is principally a political lesson like the aforementioned discoveries, equally pertinent today, that liberalism might not always be compatible with the aspirations of social democracy, or that an unrestricted franchise might democratically bring about the election of right-wing governments hostile to social democracy, if not even to democracy itself. Since ,social democracy“ can sometimes seem like an oxymoron in practice, particularly when concurrent with the fickle workings of ,political democracy“, there should be some limits to exaggerating the importance of public proclamations made by radicals regarding current events, whether in print or in speech. This seems worth bearing in mind if one's aim is to claim that such proclamations capaciously constitute ,democratic“ acts as significant as those affecting who has control over the government or influential attempts to change the nature of that control. ${ }^{40}$ Traditional left-wing research attachments to the study of certain social categories supposedly emblematic of the forward march of social democracy (militant workers, feminists, radical intellectuals, etc.) are often marshalled in the service of dredging up figures from the past in retrospective surveys celebrating how their causes proleptically prefigured the values of today's most enlightened progressives, or the sorts of problematics those values raise. ${ }^{41}$

39 On the effects this interest in ,modernization“ once had on historical research on 1848, notably in the wake of Charles Tilly's early work on social protest in French history, see Edward Berenson's comparative Franco-German survey, Organization and „Modernization“ in the Revolutions of 1848, in: D. Howe et alii, Europe in 1848, p. 560-582.

40 For an attempt to examine the 1848 French case recognizing the need to focus on the contradictions resulting from simultaneous demands on the government for greater levels of democracy and greater levels of state intervention to alleviate poverty and the confusions created by the ensuing interpenetration of political and social demands, see Giovanna Proccacci's suggestive essay, To Survive the Revolution or to Anticipate It? Governmental Strategies in the Course of the Crisis of 1848, in D. Howe et alii, Europe in 1848, p. 507-527.

41 For an example of such an approach, see, despite its impeccable scholarship, Thomas Bouchet's recent survey, Les Fruits défendus. Socialismes et sensualité du XIXe siècle à nos jours, Paris 2014, which explores why Francophone socialists since the time of Charles Fourier have had difficulty embracing twenty-first-century conceptions of sexuality and sensuality which Fourier and some subsequent 
Although not discrediting them exactly, periodic popular rejection of such values seems to suggest that there are social and political limits to the proliferation of discourses of improvement, and the story of the spectacular rise and defeat of the plural representatives of social democracy under the French Second Republic is no exception.

\section{Moving Beyond the Present in the Past}

The complexities and ambiguities of the motivations behind the militancy of early nineteenth-century French manual workers, socialists, communists, and feminists - along with the attendant complexities and ambiguities of left-wing intellectuals' motivations for prioritizing the interests of workers and women - was very much the subject of Jacques Rancière's path-breaking La Nuit des Prolétaires and his early writings from the 1970s and early 1980s, themselves, in many ways, the product of a critical disengagement from the French Maoism of the 1960s and the collected works of Louis Althusser, made through the lens of a reexamination of nineteenth and early twentieth-century French socialist history. ${ }^{42}$ One regrets that many French scholars today, often openly inspired by Rancière's more recent political writings on ,disagreement“, ,,dissensus“, and the „hatred of democracy“, have forgotten Rancière's earlier nuanced attention to the reasons, whether opaque or transparent, behind why individuals adopt their politics. ${ }^{43}$ I have already alluded to the complications vitiating Marx's own narrative accounts of what happened in France between 1847 and 1852; the same could be said of other contemporary

select others anticipated. Undoubtedly the topic of socialist attitudes towards sexual relations is a worthy one, although I am not so sure that it can be so easily separated from questions of reproduction, at least prior to the generalization of female contraception in the second half of the twentieth century. Indeed, the sorts of political tensions between liberal democracy and socialism repeatedly underscored above in many ways have found a parallel echo from the nineteenth century onwards even until today in those tensions arising between progressive reformers' desire for greater sexual liberalism and their simultaneous desire to improve qualitatively the division of labor in societies wherein heterosexual reproductive intercourse and individuated family structures respectively remain in some form or other important to both childbearing and childrearing. The antinomies of individual freedom and the propensity of humans to reproduce themselves in monogamous heterosexual family units were at the heart of the nineteenth-century ,woman question “, and it is no surprise that answering this question seemed more pressing than in previous centuries once the „,social question“ was posed with particular acuity.

42 Besides Jacques Rancière, La Nuit des Prolétaires: Archives du rêve ouvrier, Paris 1981, I am thinking of Rancière's diverse articles from the 1970s published in Les Révoltes logiques, collected and republished as IDem, Les Scènes du Peuple 1975-1985, Paris 2003, and IDEM, Le Philosophe et ses pauvres.

43 For Rancière's more recent evolution since the 1990s, see notably Jacques Rancière, La Mésentente, Paris 1995; and IDEM, La Haine de la démocratie, Paris 2005. 
accounts from the same period, regardless of the political stripe of their author. ${ }^{44}$

Underscoring the highly subjective dimension to such observers' engagement with their time in formulating arguments about it seems all the more important given that expressions of political and social thought are rarely systematic, and are almost always fluid and dynamic, reacting to the present as it changes, much like changing perspectives about the significance of the Revolutions of 1848. For intellectual historians, this means, in light of the "linguistic turn“ made by Anglo-American social historians in the late 1980s and early 1990s and the widespread recognition that the language used to describe politics and society contains a performative capacity structuring experience, that one must be particularly attentive to how events are described since the overlap between description and prescription is always present to some degree in speech acts, making a healthy dose of analytical skepticism, coupled with hermeneutical sensitivity, all the more necessary for the conscientious historian. It also suggests that the more familiar the ideas of an author from the past seem, the greater the need for exegetical agnosticism. Indeed, perhaps the goal of intellectual historians working today on the nineteenth century and afterwards should be to make ,,modern“ thinkers less „modern“ precisely so that those thinkers' contributions to our understanding of the course of political and social thought can better be measured. For example, recent studies of Marx have emphasized how much Marx was a cultural product of the nineteenth century, particularly of pre-1848 Europe. ${ }^{45}$ Such studies suggest not only that in order ever to understand Marx's ideas, one must begin by separating Marx from „Marxism“, to the extent that the latter is thought of to be a coherent body of thought largely invented by Engels and his successors after Marx's death. ${ }^{46}$ They also suggest more generally and by way of implication that it is a worthwhile enterprise to attempt to separate other ,modern“ authors from the ,,ideologies“ they supposedly founded and from histories of those same ideologies. The same point could be made about the intellectual origins of , anarchism“, whose twentieth-century hagiographical histories

44 For another specific example of this, see Thomas C. Jones, Les Révolutions historiques de Louis Blanc et la mémoire de 1848 en France et en Grande Bretagne, in: E. Castleton - H. Touboul, Regards sur 1848 , p. 115-149. For a masterful literary study of a number of different writers' assessments of their experience of the Revolution of 1848 in France more generally and the June Days in particular, see classic Dolf Oenler, Ein Höllensturz der Alten Welt zur Selbsterforschung der Moderne nach dem Juni 1848, Frankfurt am Main 1988 and the recent enlarged reedition of this work in French translation, IDEM, Juin 1848, le spleen contre l'oubli. Baudelaire, Flaubert, Heine, Herzen, Marx, Paris 2017.

45 Notably, in very different ways, in Jonathan Sperber, Karl Marx: A Nineteenth-Century Life, New York 2013; and G. Stedman Jones, Karl Marx. Stedman Jones suggestively underscores how such pre-1848 intellectual influences made it difficult for Marx to assess social and political changes during his London exile.

46 This point is particularly stressed in Stedman Jones's intellectual biography. 
have often resuscitated marginal figures from the nineteenth century to transform them into canonical figures. ${ }^{47}$ And the identical point could be made with regards to „liberalism“, given, for example, the questionable twentieth-century transatlantic transformation and apotheosis of Tocqueville during the Cold War and after into a prophet who foresaw all things good and bad about the modern world. ${ }^{48}$

Having abandoned many of the teleological assumptions underlying larger narrative accounts of the course of the nineteenth-century past (about modernization and social protest, the true nature of class struggle, the necessary alliance between political and social democracy, etc.), we can at last begin to examine the origins of various nineteenth-century contemporaries' attempts to construct these influential narrative accounts and thereby better understand how we came to think the way we do about politics and society as we learn how they did with often mixed results and in very different social and political contexts. ${ }^{49}$ If one accepts as a given from the outset the fragile veracity of different contemporaries' accounts of

47 This has been largely a consequence of the work of Max Nettlau, who was responsible for the first authoritative histories of anarchism in the late nineteenth and early twentieth centuries, selectively introducing eccentric figures like Joseph Déjacque and Ernest Coeurderoy to a canon of left-wing worthies he almost singlehandedly created. Attempts to replicate Nettlau's herculean bibliographical efforts have followed his general political orientation, by, for example by, excluding less obviously left-wing anti-authoritarian publicists like the aforementioned Girardin, or to take another example, de-emphasizing the economic liberalism of Max Stirner. For my own modest contribution to the revision of conventional histories of anarchism, see Edward CASTLETON, The origins of , collectivism": Pierre-Joseph Proudhon's contested legacy and the debate about property in the International Workingmen's Association and the League of Peace and Freedom, Global Intellectual History 2, July 2017, Nr. 2, p. 169-195.

48 On Tocqueville's strange afterlife, see Serge Audier, Tocqueville retrouvé. Genèse et enjeux du renouveau tocquevillien français, Paris 2004. The various attempts to transform Adam Smith and Jean-Baptiste Say into advocates of unbridled free-market economic liberalism have been equally questionable. The revisionist literature on Smith in the past thirty years countering this characterization is immense. See Keith Tribe's assessment of how this transformation of Smith first occurred, , Das Adam Smith Problem and the Origins of Smith Scholarship, in: idem, The Economy of the Word, p. 139-167. On Say, see R. Whatmore, Republicanism and the French Revolution. In a similar revisionist vein, Gregory Claeys's reevaluation of the scope of John Stuart Mill's political liberalism in Gregory Claeys, Mill and Paternalism, Cambridge 2013.

49 This would mean first breaking with the tendency to look first and foremost for ,actuality “ in nineteenth-century authors, possibly a problem in places like France where respectable scholarly journals exist with titles like Actuel Marx and books are sold with titles like Proudhon contemporain. But such a change of focus seems all the more necessary given that the alternative to revising conventional wisdom about the birth of modern political ideologies is to leave our already revised understanding of the nineteenth century as bereft of ideas as of any underlying teleological historical narrative. For an exemplary attempt at synthesizing current anti-teleological revisionist accounts of nineteenth-century French history, see the recent bibliographical compendium and historiographical survey done by Emmanuel FurEIX - François JARrige, La modernité désenchantée. Relire l'bistoire du XIXe siècle français, Paris 2015. 
the European Revolutions of 1848-1849, one can perhaps better appreciate how those same contemporaries sought to inscribe and re-inscribe their perceptions of revolutionary events within a larger teleological vision of where their world was going, thereby hoping to gain some illusive narrative mastery over their present. Such efforts are particularly obvious in the most perceptive writers of the era, ones as ideologically different as Alexander Herzen, Proudhon, Marx, Stein, József Eötvös, Tocqueville, or Donoso Cortès. ${ }^{50}$

In the twentieth century, the German postwar historian Reinhart Koselleck famously worked from his insight into the importance of „Futures Past“ (Vergangene Zukunft) in political and social thought, to argue that the period between 1750 and 1850 comprised a Sattelzeit era in European history, during which prospects of reform and revolution dominated all conceptual attempts to come to terms with the present, and that these conceptual innovations ushered in modernity. Koselleck and many of his German comrades in Begriffsgeschichte (some of whom had pre-war national socialist pasts or personal combat experience in World War II), sought to fuse the history of ideas with social and political history in order better to understand history's losers, albeit for very different political reasons than those largely academic ones motivating the Anglo-American ,linguistic turn". ${ }^{51}$ Their method could just as equally have been applied to the period between 1848 and 1948, one very much their own, which so troubled the person who was, in many respects, their intellectual mentor, Carl Schmitt. After all, this later chronological period, perhaps yet another Sattelzeit, was an era characterized by such Schmittian problems as the expansion of suffrage; civil unrest; socialism and communism vs. anti-socialism and anti-communism; hostility to parliamentary democracy; states of emergency; political legitimacy divorced from hereditary monarchies; authoritarian dictatorships; unshackled nationalism and racism; and international instability. ${ }^{52}$

50 Herein, one need only look at how much Marx's own interpretation of political events in France evolved between the publication of his first articles on the topic in the Neue Rheinische Zeitung and that of The Eighteenth Brumaire. I have explored the dynamic process by which Proudhon interpreted French political life between 1847 and 1852 in E. CAstleton, The Many Revolutions of Pierre-Joseph Proudhon, p. 39-69. For examinations of similar attempts made by radicals and revolutionaries to make retrospective sense of events they could not control, see also Diana SicLovan, 1848 and German Socialism, in: D. Moggach - G. Stedman Jones (edd.), The 1848 Revolutions and European Political Thought, p. 254-275, as well as J.-Ch. Angaut, Revolution and the Slav Question.

51 On Koselleck's Begriffsgeschichte project in comparison with other attempts to examine the history of political thought, see Melvin Richter, The History of Political and Social Concepts, Oxford 1995. For how Koselleck specifically attempted to apply his approach to the study of Prussian modernization, see Keith TRIBE's recent essay, Revision, Reorganization, and Reform: Prussia, 1790-1820, in B. Kapossy et alii (edd.), Markets, Morals, Politics, p. 136-160.

52 Quite independently of Schmitt and his Germanophone legacy, these are many of the themes of two works by Arno MAYE r, Dynamics of Counterrevolution in Europe, 1870-1956: An Analytic 
In our own teleophobic age, long since post-Auschwitz and post-Hiroshima, currently branded ,the Anthropocene“, it is hard not to be a pessimist about the future, especially for those who consider themselves to be on the side of progress and enlightenment. Whatever our Koselleckian ,horizon of expectation“ might be, it is certain to be different from those plural visions which drove the course of the European Revolutions of 1848. But in a more optimistic revolutionary era, seemingly full of possibilities like that of the mid-nineteenth century, how contemporaries anxiously sought to identify the immanent telos leading, for better or for worse, from current events to their imminent future was undeniably as critical to their understanding of their present as their grasp of the past that led them there. This is one reason why historians of 1848 must ask themselves, as best they can, independently of their own prejudices, what did the authors of the particular texts they study genuinely want and why. To this end, they should try and capture the open-ended immediacies and particularities contained within contemporaries' attempts to give some semblance of meaning to what so quickly and unpredictably happened in mid-nineteenth century Europe.

Historical work on 1848 in France, or elsewhere, will largely remain as much a prisoner to the futurist content of „,modern“ attempts to render relevant visions and revisions of revolution as the writings of those individuals who first tried to figure out what exactly transpired that fateful year and the years that followed..$^{53}$ At least we can struggle to be conscious of this mercurial truth about

Framework, New York, NY 1971, and his once highly influential IDEM, The Persistence of the Old Regime: Europe to the Great War, New York, NY 1981. Both certainly could certainly be revisited in light of a careful study of the different forms of European reaction the Revolutions of 1848 inspired on the Continent and their discursive differences from the counter-revolutionary arguments provoked in the wake of the French Revolution. A starting point for such an approach could be Roger Price's survey essay, ,"The Holy Struggle Against Anarchy“: The Development of Counter-Revolution in 1848 , in: D. Howe et alii, Europe in 1848, p. 25-54. Indeed, it might be that the concept of ,class war" and its language gained much more traction through the efforts of socialism's enemies than its proselytizers. See, on this subject and the related one of the emergence of a rhetoric of ,civil war“ in the France of 1848, Jean-Claude CARON, Frères de sang: la guerre civile en France au XIXe siècle, Seyssel 2009; Emmanuel Fureix, Mots de guerre civile. Juin 1848 à l'épreuve de la representation, Revue d'histoire du XIXe siècle 15, 1997, Nr. 2, p. 21-30; and the first section of D. Oenler, Ein Höllensturz der Alten Welt. On Schmitt's specific interest in 1848 and the mid-nineteenth century crisis of traditional conceptions of political legitimacy and authority as discussed in relation to the ideas of Donoso Cortès, Stein, and Tocqueville, see his collected essays in Carl Sснмiтt, Donoso Cortés in gesamteuropäischer Interpretation. Vier Aufsätze, Cologne 1950; IDEM, Die Stellung Lorenz von Steins in der Geschichte des 19. Jahrunderts, Schmollers Jahrbuch fur Gesetzgebung, Verwaltung und Volkswirtschaft im Deutschen Reiche 64, 1940, Nr. 6, p. 641-646; and Historiographia in nuce: Alexis de Tocqueville" (1940), republished in IDEM, Ex Captivitate Salus. Erfahrungen der Zeit 1945-1947, Cologne 1950, p. 25-33.

53 For an overview some of the discursive innovations made by contemporaries in their attempts to make sense of the events of 1848, see Hélène Desbrousses - Bernard Peloille, Révolution de 
the palimpsestic nature of interpretations of revolutionary events. Our future might seem considerably less full of emancipatory possibilities than the past. But it also might just be that by striving better to move two centuries backwards, we can move one step forward in our own time and exit the seemingly eternal recurrence of political cycles of hope and disappointment of which the revolutionary and counter-revolutionary events of 1848 now appear so emblematic.

1848: un décryptage du palimpseste, Mots 69, June 2002, p. 23-44. For an examination of how conceptions of the future affected French socialists' conceptions of the past during the later Third Republic, see Julian WRIght, Socialism and the Experience of Time: Idealism and the Present in Modern France, Oxford 2017. 


\section{Edward Castleton}

\section{Untimely Meditations on the Revolution of 1848 in France}

\section{(Abstract)}

This article examines current discussions of the European Revolutions of 1848 in light of the larger evolution of Anglo-American and French historiography since the second half of the twentieth century. Although focusing in particular on French history, the article suggests why some knowledge of the trends driving this evolution is necessary for improving our understanding of 1848's political and social importance.

\section{KEY WORDS}

Historiography; France; Revolution 1848; slavery; Gareth Stedman Jones 